\title{
PENINGKATAN KEMAMPUAN PEMECAHAN MASALAH MATEMATIKA SISWA MELALUI MODEL PEMBELAJARAN LAPS- HEURISTIC DIKELAS X SMAN 2 BATANG ANAI
}

\author{
Witna Susanti ${ }^{1}$, Adri Nofrianto ${ }^{2}$, \& Mira Amelia Amri ${ }^{3}$ \\ 1witna.aza@gmail.com, ${ }^{2}$ adrinofrianto@gmail.com, ${ }^{3}$ miraameliaamri@gmail.com \\ ${ }^{123}$ Sekolah Tinggi Keguruan Dan Ilmu Pendidikan, Padang Pariaman/Sumatera Barat \\ 2016
}

\begin{abstract}
Abstrak
Penelitian ini bertujuan untuk mengetahui peningkatan kemampuan pemecahan masalah matematika siswa melalui model pembelajaran LAPS-Heuristic. Jenis penelitian ini yaitu penelitian deskriptif kualitatif. Subjek dalam penelitian ini dipilih dua siswa dari kelas penelitian yaitu kelas X SMAN 2 Batang Anai. Subjek yang dipilih dalam merupakan siswa yang memiliki kemampuan matematika tinggi. Data dikumpulkan melalui tes pemecahan masalah dan wawancara. Hal ini dilakukan sebelum dan sesudah penerapa model pembelajaran LAPS-Heuristic. Berdasarkan hasil deskripsi dan analisis data, dapat dilihat perkembangan kemampuan pemecahan masalah matematika siswa meningkat pada saat dilakukan tes akhir. Pada hasil penilaian berdasarkan rubrik pemecahan masalah matematika, diperoleh tingkat kategori sangat memuaskan dengan indikator pencapaian: memahami soal dengan benar, rencana strategi penyelesaian yang benar, mengarah pada jawaban yang benar dan adanya pengecekan kembali hasil perhitungan, sehingga dapat disimpulkan bahwa model pembelajaran LAPS-Heuristic berpengaruh terhadap kemampuan pemecahan masalah matematika siswa kelas X SMAN 2 Batag Anai.
\end{abstract}

Kata kunci: kesulitan matematika, pemecahan masalah, LAPS-Heuristic

\footnotetext{
Abstract

This research aims to determine the increase in mathematics problem solving ability of students through learning model LAPS-Heuristic. Type of research is a qualitative descriptive study. The subjects in this study were selected two students from class research that is class X SMAN 2 Batang Anai. Subjects selected were the students who have high math skills. Data were collected through a problem-solving test and interview. This data collection was done before and after the implementation of learning model LAPS-Heuristic. Based on the description and analysis of the test, it can be seen that the development of mathematical problem solving ability of students increased at the time of the final test. The results of the assessment under the rubric of mathematical problem solving, showcased very satisfactory level categories with indicators of achievement: understand the question correctly, the correct completion of strategic plans, leading to a correct answer and rechecking their calculation. Hence, it can be concluded that the
} 
model of LAPS-Heuristic affects the ability of Mathematical Problem Solving of Tenth Graders at SMAN 2 Batag Anai.

Keywords: mathematical difficulty, problem solving, LAPS-Heuristic

\section{Pendahuluan}

Matematika merupakan salah satu disiplin ilmu yang mampu mengembangkan kemampuan berpikir logis, kritis, sistematis dan kreatif, yang sangat berguna dalam pemecahan masalah yang dihadapi oleh setiap manusia. Hal ini sesuai dengan tujuan pembelajaran matematika yang dirumuskan dalam Kurikulum Satuan Tingkat Pendidikan (KTSP) yang menyatakan bahwa pelajaran matematika perlu diberikan kepada semua peserta didik dari sekolah dasar untuk membekali peserta didik untuk meningkatkan kemampuan berpikir logis, analitis, sistematis, kritis dan kreatif, serta kemampuan bekerjasama.

\section{Nasional Council of Teachers of} Mathematic (NCTM, 2000) menetapkan 5 standar kemampuan matematis yang harus dimiliki oleh siswa, yaitu kemampuan pemecahan masalah (problem solving), kemampuan komunikasi (communication), kemampuan koneksi (connection), kemampuan penalaran (reasoning) dan kemampuan repsresentasi (representation). Berdasarkan uraian diatas, dapat disimpulkan bahwa kemampuan pemecahan masalah dalam pembelajaran matematika merupakan hal penting yang harus dikembangkan dan dimiliki oleh setiap siswa. Dalam proses belajar dikelas, siswa perlu dibiasakan untuk memecahkan masalah, menemukan sesuatu yang berguna bagi dirinya dan mampu mengaplikasikan ide-ide mereka dalam belajar. Akan tetapi, dalam pelaksanaannya siswa dan guru mengalami kesulitan dalam mengembangkan maupun meningkatkan kemampuan pemecahan masalah matematis (Suherman dkk, 2003) menyatakan guru mengalami kesulitan dalam mengajarkan bagaimana cara menyelesaikan masalah matematis dengan baik, siswa juga menghadapi kesulitan bagaimana menyelesaikan masalah yang diberikan guru.
Kesulitan dalam pemecahan masalah juga ditemukan di SMAN 2 Batang Anai yang dilihat dari wawancara yang telah dilakukan, rendahnya kemampuan pemecahan masalah siswa disebabkan oleh beberapa faktor, diantaranya; (1) siswa kesulitan dalam memahami soal; (2) siswa kesulitan dalam menentukan langkah awal untuk menyelesaikan soal tersebut; (3) siswa menganggap rumus matematika itu rumit; (4) siswa kesulitan dalam mengingat rumus matematika; (5) siswa kesulitan dalam mengaplikasikan konsep matematika dalam memecahkan masalah matematika; (6) dalam merencanakan penyelesaian masalah siswa hanya menggunakan satu ide, jadi kreativitas siswa dalam pemecahan masalah masih kurang. Berdasarkan pernyataan tersebut dapat disimpulkan bahwa siswa kesulitan dalam menemukan ide-ide dalam pemecahan masalah, akhirnya siswa menjadi patah semangat dalam menyelesaikan soal pemecahan masalah.

Mengatasi masalah diatas penulis mencoba menerapkan model pembelajaran Logan Avenue Problem Solving (LAPS)Heuristic. Model pembelajaran LAPS-Heuristic ini memberi kesempatan kepada siswa untuk menyelesaikan persoalan tidak rutin dengan tuntunan berupa pertanyaan yang diperlukan untuk menyelesaikan suatu masalah. Oleh karena itu, kemampuan pemecahan masalah dibangun oleh siswa itu sendiri. Hal ini sesuai dengan pendapat (Nurdin dalam Shoimin, 2014) bahwa "Heuristic adalah suatu penuntun berupa pertanyaan yang diperlukan untuk menyelesaikan suatu masalah". Selanjutnya Nurdin menjelaskan bahwa "Heuristic juga berfungsi mengarahkan pemecahan masalah siswa untuk menemukan solusi dari masalah yang diberikan".

Model LAPS-Heuristic memfasilitasi siswa untuk menyelesaikan permasalahan non rutin. Masalah non rutin ini memberikan 
kesempatan kepada siswa untuk menyelesaikan masalah didefinisikan sebagai suatu persoalan yang tidak rutin belum dikenal cara penyelesaiannya, kemudian dicari jalan keluar untuk mengetahui kunci untuk mencari atau menemukan cara penyelesaian. Dalam menyelesaikan soal digunakan kata tanya apa masalahnya, adakah alternatif, apakah bermanfaat, apakah solusinya, dan bagaimana sebaiknya mengerjakannya. Maka dari itu model pembelajaran LAPS-heurstic dapat mempengaruhi kemampuan pemecahan masalah matematika siswa.

Identifikasikan masalah dalam penelitian ini adalah sebagai berikut:

1. Siswa kesulitan dalam memahami soal,

2. Siswa kesulitan dalam menentukan langkah awal untuk menyelesaikan soal pemecahan masalah,

3. Siswa menganggap rumus matematika itu rumit,

4. Siswa kesulitan dalam mengingat rumus matematika,

5. Siswa kesulitan dalam mengaplikasikan konsep matematika dalam memecahkan masalah matematika,

6. Bahwa siswa dalam merencanakan penyelesaian masalah hanya menggunakan satu ide.

Berdasarkan latar belakang di atas, maka dilakukan penelitian dengan judul peningkatan kemampuan pemecahan masalah matematika siswa melalui model pembelajaran LAPSHeuristic.

\section{Kemampuan Pemecahan Masalah}

Menurut polya (1973) (dalam hudoyo, 2003:112) pemecahan masalah adalah sebagai usaha untuk mencari jalan keluar dari suatu kesulitan, mencapai suatu tujuan yang tidak dengan segera dapat dicapai. Berdasarkan uraian diatas tampak bahwa pemecahan masalah sangat penting dalam menyelesaikan pemecahan masalah untuk mencari jalan keluar dari suatu permasalahan yang diterima oleh semua orang. Maka dari itu pentingnya pemecahan masalah dalam menyelesaikan permasalahan matematika. Pemecahan masalah matematika dapat mengajarkan siswa dalam menyelesaikan masalah-masalah yang memungkinkan siswa tersebut menjadi lebih kritis dan analitis dalam menentukan konsep yang sesuai dengan permasalahan. Oleh sebab itu, pemecahan masalah matematika yang diberikan kepada siswa akan mampu memotivasi siswa dalam mempelajari pelajaran tersebut.

\section{Penelitian Relevan}

Penelitian yang relevan dengan penelitian ini ada dua yaitu 1) penelitian Sri Wahyuni, Universitas Negeri Semarang (2015) yang berjudul "pengembangan karakter kedisiplinan dan kemampuan pemecahan masalah melalui model LAPS-Heuristic materi lingkaran kelas-VIII". Memberikan hasil bahwa penerapan metode pembelajaran LAPS-Heuristic pada mata pelajaran matematika telah memberikan pengaruh lebih besar terhadap kemampuan pemecahan masalah matematika siswa. Pengembangan yang diberikan yaitu latihan soal pemecahan masalah yang cukup dari segi kualitas dan kuantitas. Latihan yang diberikan terdiri dari dua tahapan, yaitu latihan dengan bantuan dan latihan secara mandiri. Latihan dilakukan dalam suasana pembelajaran yang menantang, bermakna dan menyenangkan. Peningkatan hasil tes kemampuan pemecahan masalah dari sampel yang telah ditentukan berturut-turut 100; 100; 94,3; 88,6; dan 84,2. 2) Yuliati, Universitas Sebelas Maret Surakarta (2015) yang berjudul upaya meningkatkan keaktifan belajar dan kemampuan kognitif matematika pada pokok bahasan aljabar dengan model LAPS-Heuristic model Polya dikelas VII. Peningkatan kemampuan kognitif matematika siswa pada siklus I diperoleh rata-rata kemampuan kognitif matematika siswa adalah 50,611dan persentase siswa yang memiliki kemampuan kognitif diatas KKM yang telah diterapkan yaitu $40 \%$. Hal tersebut menunjukkan terjadinya peningkatan, sebelum dilakukan tindakan rata-rata kemampuan kognitif siswa adalah 48,8. Pada siklus II peningkatan kemampuan kognitif matematika siswa diperoleh rata-rata kemampuan kognitif matematika siswa adalah 64,1 dan persentase siswa yang memiliki 
kemampuan kognitif diatas KKM yang telah diterapkan mengalami peningkatan sebesar $36 \%$ dari siklus I yaitu mencapai $76 \%$.

\section{Metode Penelitian}

Jenis penelitian dalam penelitian ini adalah penelitian deskriptif kualitatif. Penelitian kualitatif ini mendeskripsikan kemampuan pemecahan masalah matematika siswa setelah diterapkan model pembelajaran LAPS-Heuristic. Maka dari itu penelitian yang tepat untuk penelitian ini yaitu penelitian deskriptif kualitatif. Penelitian ini dilakukan di SMAN 2 Batang Anai kecamatan Batang Anai. Subjek dalam penelitian ini yaitu kelas $\mathrm{X}_{1}$ yang dibedakan menjadi dua bagian, 1) kelas penelitian adalah semua siswa kelas $\mathrm{X}_{1}$ yang akan diberi perlakuan LAPS-Heuristic, 2) subjek penelitian yaitu siswa kelas $X_{1}$ yang akan diberikan soal pemecahan masalah dan yang akan di wawancarai. Penentuan sumber data dalam penelitian ini digunakan teknik purposive sampling, yaitu dipilih dengan pertimbangan dan tujuan tertentu Sugiyono (2013:300). Pertimbangan dalam menentukan subjek adalah, 1) kemampuan pemecahan masalah matematika siswa, 2) kemampuan komunikasi siswa dalam wawancara. Sampel dalam penelitian ini dipilih dua siswa dari kelas penelitian yaitu kelas $\mathrm{X}_{1}$. Sebelum memasuki pertemuan pertama dalam penelitian dilakukan tes kemampuan matematika untuk menentukan dua orang siswa yang memiliki kemampuan tinggi. Soal yang diberikan untuk tes kemampuan matematika yaitu soal UN SMP tahun 2014 prediksi 1, yang mana soal tersebut sudah teruji validitas, reliabilitas dan indeks kesukarannya. Setelah itu dianalisis hasil tes tersebut dan ditentukan subjek penelitiannya yaitu dua orang siswa yang berkemampuan tinggi.

Instrumen dalam penelitian ini terdiri dari 2, yaitu instrumen utama dan instrumen pendukung, instrumen pendukung terdiri dari soal pemecahan masalah dan pedoman wawancara.

1. Instrumen Utama

Menurut Sugiyono (2014:222) dalam penelitian kualitatif, yang menjadi instrumen atau alat penelitian adalah peneliti itu sendiri. Oleh karena itu peneliti sebagai instrumen juga harus 'divalidasi' seberapa jauh peneliti kualitatif siap melakukan penelitian yang selanjutnya terjun kelapangan. Validasi terhadap peneliti sebagai instrumen meliputi validasi terhadap pemahaman metode penelitian kualitatif, penguasaan wawasan terhadap bidang yang diteliti, kesiapan peneliti dalam memasuki obyek penelitian, baik secara akademik maupun logistiknya.

2. Instrumen Pendukung

Instrumen pendukung dalam penelitian ini ada 2, yaitu soal pemecahan masalah dan pedoman wawancara.

a. Soal Pemecahan Masalah

Soal pemecahan masalah dalam penelitian ini adalah soal yang tidak dapat langsung dijawab oleh individu untuk menemukan solusi dari pertanyaan tersebut. Jadi masalah yang diberikan adalah masalah kemampuan pemecahan masalah matematika siswa. Soal dalam pemecahan masalah dalam penelitian ini diberikan kepada subjek penelitian yang terdiri dari soal pemecahan masalah awal dan akhir. Validitas yang digunakan dalam penelitian ini adalah validitas isi. Tes dikatakan memiliki validitas isi apabila mengukur tujuan khusus tertentu yang sejajar dengan materi atau isi pelajaran yang diberikan (Arikunto, 2013:82). Tujuannya adalah untuk mengetahui sampai dimana kemampuan pemecahan masalah matematika siswa. Validitas isi dalam penelitian ini dilakukan dengan mencocokkan materi tes awal yang digunakan dengan silabus, kisi-kisi dan mencermati kembali langkah-langkah yang digunakan dalam menjawab tes yang diberikan.

b. Pedoman Wawancara

Wawancara yang dilakukan dalam penelitian ini adalah wawancara semiterstruktur. Pedoman wawancara terdiri dari beberapa pertanyaan-pertanyaan yang merupakan gambaran umum dari kemampuan pemecahan masalah. Indikator-indikator penilaian sama dengan kemampuan 
pemecahan masalah siswa, yang berbeda hanya metode pengumpulannya saja. Langkah-langkah yang dilakukan untuk menyusun pedoman wawancara adalah; (1) merumuskan tujuan wawancara; (2) membuat kisi-kisi; (3) menyusun pertanyaan sesuai indikator dan (4) membuat pedoman wawancara.

3. Pengumpulan Data

a. Tes Pemecahan Masalah

Tes pemecahan masalah dilakukan diawal dan diakhir penelitian. Tes awal dilakukan sebelum diterapkan model pembelajaran LAPS-Heuristic dan tes akhir dilakukan sesudah diterapkannya model pembelajaran LAPS-Heuristic.

b. Wawancara Semiterstruktur

\begin{tabular}{lrr}
\multicolumn{2}{c}{ Wawancara } & semiterstruktur \\
digunakan untuk & mengeksplorasi \\
perkembangan kemampuan & pemecahan \\
masalah matematika siswa. & Wawancara
\end{tabular}
semiterstruktur terdiri dari pertanyaan yang terkait dengan indikator tes pemecahan masalah dan pengembangan tes dasar atas jawaban siswa. Jenis pertanyaan pendalaman, maka akan memperlihatkan bagaimana cara mereka berpikir melalui pernyataan yang mereka berikan.

\section{Tahap Analisis Data}

Pada tahap analisis data, data yang telah dikumpulkan dianalisis atau diolah sesuai dengan metode-metode yang telah ditentukan. Kegiatan yang dilakukan pada tahap pengolahan data adalah; (1) mengumpulkan data nilai tes akhir dan wawancara mengenai kemampuan pemecahan masalah; (2) mengolah dan menganalisis data berupa hasil tes awal dan tes akhir kemampuan pemecahan masalah subjek penelitian, serta menganalisis hasil wawancara; (3) tahap pembuatan kesimpulan kegiatan yang dilakukan adalah membuat kesimpulan berdasarkan data-data yang diperoleh; (4) tahap penyusunan laporan, pada tahap ini hasil-hasil penelitian disusun dan dilaporkan. Penyusunan laporan sesuai dengan sistematika panduan penulisan skripsi STKIP Dharma Bakti Lubuk Alung.
Analisis data dalam penelitian kualitatif, dilakukan pada saat pengumpulan data berlangsung, dan setelah selesai pengumpulan data dalam periode tertentu. Pada saat wawancara, pewawancara sudah melakukan analisis terhadap jawaban yang diwawancarai. Bila jawaban yang diwawancarai setelah dianalisis terasa belum memuaskan, maka pewawancara akan melanjutkan pertanyaan lagi, sampai tahap tertentu, diperoleh data yang dianggap kredibel. Menurut Miles and Huberman (Sugiyono, 2014:246) aktivitas dalam analisis data terdiri diri 3 langkah, yaitu data reduction, data display, dan conclusion drawing/verification. Berikut penjelasan masingmasing langkah analisis data.

\section{a. Data Reduction/Reduksi Data}

Melalui reduksi data, data dari tes awal pemecahan masalah dan wawancara akan dirangkum, dipilih hal-hal yang pokok, difokuskan pada hal-hal yang penting, dicari tema dan polanya. Dengan demikian data yang telah direduksi akan memberikan gambaran yang lebih jelas dan mempermudah penulis untuk melakukan pengumpulan data selanjutnya dan mencarinya bila diperlukan. Reduksi data pada penelitian ini dilakukan sebelum pengumpulan data, di dalam proses pengumpulan data, dan setelah pengumpulan data.

\section{b. Data Display/Penyajian Data}

Pada proses ini, data yang dibahas mengenai kemampuan pemecahan masalah siswa dalam pemecahan masalah matematika setelah mereka diajarkan dengan LAPSHeuristic. Sehingga, informasi yang diperoleh dalam bentuk uraian singkat, bagan, hubungan antar kategori. Flowchart dan tindakan lanjut yang perlu dilakukan. Tujuan utama dari proses mendisplaykan data adalah untuk memudahkan memahami apa yang terjadi, merencanakan kerja selanjutnya berdasarkan apa yang telah dipahami tersebut.

c. Conclusion Drawing/Verification

Langkah ketiga dalam analisis data kualitatif menurut Miles and Huberman adalah penarikan kesimpulan dan verifikasi. 
Penarikan kesimpulan didapatkan berdasarkan hasil proses data reduksi dan penyajian data.

Data yang dikumpulkan dalam penelitian ini yaitu data awal dan data akhir yang akan di analisis perbedaannya. Data awal berupa tes awal dan data akhir berupa tes akhir.

\section{Triangulasi Data}

Untuk menjamin keabsahan data yang dikumpulkan maka dilakukan triangulasi sumber terhadap masing-masing subjek penelitian.

\section{Hasil dan Pembahasan}

Pada bab ini akan dideskripsikan hasil penelitian mengenai peningkatan kemampuan pemecahan masalah matematika siswa melalui model pembelajaran LAPS-Heuristic yang berkesinambungan dengan hasil tes awal dan tes akhir serta hasil wawancara. Hasil penelitian ini terdiri dari deskripsi data dan pembahasan hasil penelitian.

Pengaruh model pembelajaran LAPSHeuristic terhadap kemampuan pemecahan masalah matematika dikelas X SMAN 2 Batang Anai terjadi pada setiap langkah-langkah model pembelajaran LAPS-Heuristic yaitu memahami masalah, menyusun rencana penyelesaian, melaksanakan rencana penyelesaian dan memeriksa jawaban. Berikut pengaruh model pembelajaran LAPS-Heuristic terhadap kemampuan pemecahan masalah matematika pada tes awal dan tes akhir yang terdapat pada Tabel 1.

Tabel 1 Pengaruh Model LAPS-Heuristic terhadap Kemampuan Pemecahan Masalah Pada Tes Awal dan Tes Akhir

\begin{tabular}{|l|l|}
\hline \multicolumn{1}{|c|}{ Tes Awal } & \multicolumn{1}{c|}{ Tes Akhir } \\
\hline Memahami Masalah \\
\hline $\begin{array}{l}\text { Interpretasi soal kurang } \\
\text { tepat/salah dalam } \\
\text { menginterpretasikan } \\
\text { sebagian }\end{array}$ & $\begin{array}{l}\text { Sudah memahami soal } \\
\text { dengan baik. }\end{array}$ \\
soal/mengabaikan soal & \\
\hline \multicolumn{2}{|l|}{ Menyusun Rencana Penyelesaian } \\
\hline
\end{tabular}

\begin{tabular}{|l|l|}
\hline \multicolumn{1}{|c|}{ Tes Awal } & \multicolumn{1}{c|}{ Tes Akhir } \\
\hline Memahami Masalah & \multicolumn{1}{|c|}{$\begin{array}{l}\text { Sudah menuliskan } \\
\text { rencana strategi } \\
\text { strategi yang digunakan } \\
\text { namun menyatakan } \\
\text { strategi yang digunakan } \\
\text { dalam pernyataan } \\
\text { wawancara tetapi } \\
\text { rencana strategi } \\
\text { penyelesaian soal yang } \\
\text { digunakan tidak relevan. } \\
\text { pada jawaban yang } \\
\text { benar. }\end{array}$} \\
\hline $\begin{array}{l}\text { Melaksanakan Rencana } \\
\text { pelaksanakan } \\
\text { penedur/proses yang } \\
\text { mengar dan mungkin } \\
\text { yang benar tetapi salah } \\
\text { perhitungan. }\end{array}$ & $\begin{array}{l}\text { Sudah melakukan } \\
\text { prosedur/proses yang } \\
\text { benar dan } \\
\text { mendapatkan hasil } \\
\text { yang benar. }\end{array}$ \\
\hline $\begin{array}{l}\text { Memeriksa Kembali } \\
\text { pengecekan terhadap } \\
\text { pasil jawaban yang } \\
\text { diperoleh. }\end{array}$ & $\begin{array}{l}\text { Sudah melakukan } \\
\text { pengecekan untuk } \\
\text { melihat kebenaran } \\
\text { proses. }\end{array}$ \\
\hline
\end{tabular}

Berdasarkan Tabel 1 diatas dapat disimpulkan peningkatan kemampuan pemecahan masalah matematika pada subjek penelitian. Berikut peningkatan yang terjadi pada subjek dalam menyelesaikan soal pemecahan masalah pada tes awal dan tes akhir.

1. Memahami masalah

Pada tahap memahami masalah tes awal dan tes akhir subjek penelitian akan di analisis perbandingannya.

a. Awal

Pada tahap tes awal subjek salah dalam menginterpretasikan sebagian soal. Berikut jawaban tes awal subjek penelitian yang terdapat pada Gambar 1

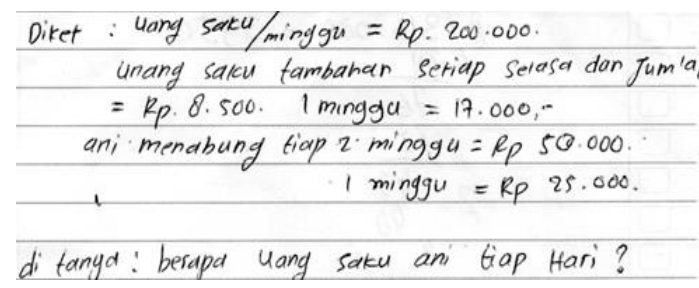

Gambar 1 Jawaban tes awal subjek

Pada Gambar 1 terlihat bahwa subjek belum memahami dengan benar apa yang 
ditanyakan soal. Karena yang ditanyakan soal yaitu uang saku ani setiap hari selain hari les. Namun subjek sudah memahami apa yang diketahui soal. Hal ini juga terlihat pada saat wawancara dengan subjek, yang terlihat di bawah ini

$\begin{array}{cl}\text { Peneliti } & \text { apa yang diketahui dari } \\ & \text { soal? } \\ \text { Subjek } & \text { yang diketahui dari soal } \\ & \text { tersebut adalah uang saku } \\ & \text { Ani perminggu Rp.200.000, } \\ & \text { kemudian uang tambahan } \\ & \text { setiap hari selasa dan jumat } \\ & \text { Rp.8.500, jadi 1 minggunya } \\ & \text { Rp.17.000, selanjutnya Ani } \\ & \text { ingin menabung tiap } 2 \\ & \text { minggu Rp.50.000, jadi } 1 \\ & \text { minggu Ani menabung } \\ & \text { Rp.25.000 } \\ & \text {.. apa yang ditanyakan dari } \\ & \text { soal tersebut? } \\ \text { Peneliti } & \text { uang saku Ani tiap hari }\end{array}$

Pada pernyataan wawancara terlihat bahwa subjek tidak memahami masalah yang diberikan. Subjek hanya membuat apa yang diketahui dan ditanyakan soal, namun subjek tidak memahami apa yang ditanyakan soal yang sebenarnya.

b. Akhir

Pada tahap akhir subjek terjadi peningkatan dalam memahami masalah, dimana subjek sudah memahami apa yang diketahui dan ditanyakan soal dengan benar. Hal ini terlihat pada Gambar 2

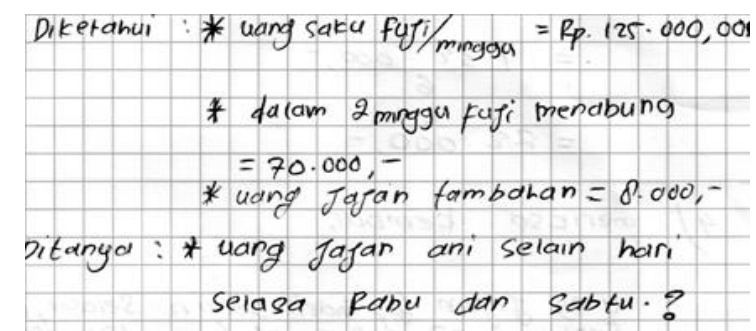

Gambar 2 jawaban tes akhir subjek

Peningkatan yang terjadi juga terlihat pada saat wawancara dengan subjek. Berikut wawancara dengan subjek pada saat wawancara memahami masalah

$\begin{array}{cl}\text { Peneliti } & \text { apa yang diketahui dari } \\ \text { Subjek } & \text { soal? } \\ & \text { uang saku fuji perminggu } \\ & \text { adalah Rp.125.000, dan } \\ & \text { dalam } 2 \text { minggu fuji } \\ & \text { menabung Rp.70.000, } \\ & \text { uang jajan yang } \\ & \text { tambahan sebesar } \\ & \text { Rp.8.000 } \\ \text { Peneliti } & \text { apa yang ditanyakan } \\ & \text { soal? subjek } \\ & \text { uang saku fuji setiap hari } \\ \text { Peneliti } & \text { selain hari les } \\ & \text { rencana apa yang } \\ & \text { ananda gunakan untuk } \\ & \text { menyelesaikan } \\ & \text { permasalah tersebut? }\end{array}$

Pada pernyataan wawancara terlihat bahwa subjek sudah memahami masalah dengan baik dan benar, hal tersebut dapat dilihat pada saat subjek menuliskan apa yang diketahui dan ditanyakan soal. Terjadi peningkatan dalam memahami masalah pada tes akhir, dimana peningkatan tersebut terjadi karena subjek sudah terbiasa dalam memnyelesaikan soal pemecahan masalah.

\section{Menyusun rencana}

Pada tahap menyusun rencana tes awal dan tes akhir subjek penelitian akan dianalisis perbandingannya. Berikut perbandingan tes awal dan tes akhir pada tahap menyusun rencana

a. Awal

Pada tes awal subjek tidak menuliskan strategi yang digunakan, namun menyatakan strategi yang digunakan dalam pernyataan wawancara tetapi rencana strategi penyelesaian soal yang digunakan tidak relevan. Berikut wawancara dengan sabjek pada saat menyusun rencana penyelesaian

\footnotetext{
Peneliti bagaimana rencana ananda untuk menyelesaikan pertanyaan yang ditanyakan soal tersebut?

Subjek pertama uang saku perminggu dikurang dengan uang tambahan setiap hari selasa dan jumat kemudian dikurang lagi dengan uang tabungan, kemudian dibagi 6

Peneliti kenapa di bagi 6?

Subjek karena perminggu waktu
} 


\section{sekolahkan ada 6 hari}

Pada pernyataan wawancara tersebut subjek hanya menyatakan rencana yang digunakan tetapi tidak menuliskan rencana yang digunakan. Namun rencana tersebut kurang sesuai dengan apa yang ditanyakan soal. Karena subjek tidak menjadikan semua uang ani ke dalam dua minggu.

b. Akhir

Selanjutnya pada tahap tes akhir subjek sudah memahami rencana yang digunakan dan mengarah pada jawaban yang benar. Hal tersebut dapat dilihat pada Gambar 3 dibawah ini

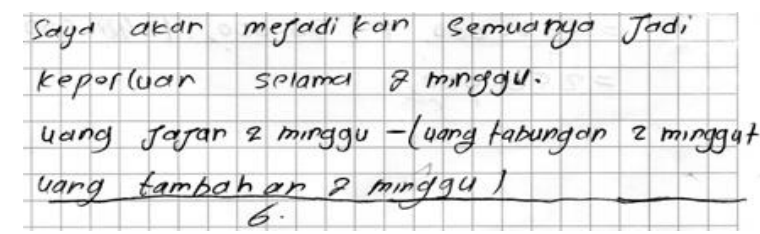

Gambar 3 jawaban tes akhir

Pada jawaban tersebut juga ditegaskan dalam wawancara dengan subjek yang dapat dilihat dibawah ini

Peneliti dari yang diketahui bagaimana rencana
ananda untuk menyelesaikan
permasalahan tersebut
Subjek
Menjadikan semua keperluan fuji selama
2 minggu, kemudian uang jajan 2
minggu dikurang dengan uang tabungan
2 minggu dikurang lagi dengan uang
yang dibutuhkan 2 minggu kemudian
semuanya dibagi 6

Peneliti kenapa dibagi 6?

Subjek setiap minggu fuji les 3 hari jadi dalam 2 minggu fuji les 6 hari

Terjadi perbedaan dalam menyusun rencana, dimana subjek sudah menuliskan rencana strategi penyelesaian yang benar dan mengarah pada jawaban yang benar. Peningkatan tersebut terlihat pada saat subjek menyatakan rencana yang digunakan, dimana rencana tersebut sesuai dengan apa yang ditanyakan soal.

3. Melaksanakan rencana
Pada tahap melaksanakan rencana tes awal dan tes akhir subjek penelitian akan dianalisis perbandingannya, berikut perbandingan tes awal dan tes akhir subjek penelitian.

a. Awal

Pada tahap tes awal subjek melaksanakan prosedur/proses yang benar dan mungkin menghasilkan jawaban yang benar tetapi salah perhitungan.. Hal tersebut dapat dilihat pada Gambar 4

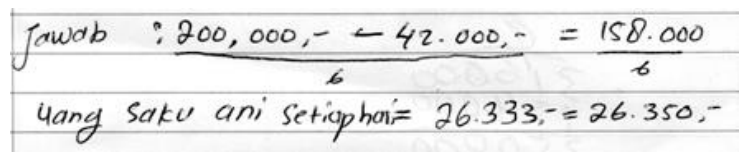

Gambar 4 jawaban tes awal

Pada Gambar terlihat bahwa subjek salah dalam melaksanakan penyelesaian, dimana subjek sudah salah dalam memahami masalah. Oleh sebab itu kesalahan tersebut juga terjadi pada saat melaksanakan rencana penyelesaian. Kesalahan tersebut juga dapat dilihat dari hasil wawancara dengan subjek sebagai berikut

\begin{tabular}{|c|c|}
\hline Peneliti & $\begin{array}{l}\text { bagaimana ananda melaksanakan } \\
\text { rencana yang telah disusun tadi? } \\
\text { Rp. } 200.000-R p .42 .000\end{array}$ \\
\hline \multirow{2}{*}{ Subjek } & 6 \\
\hline & $\begin{array}{l}=\frac{R p \cdot 158.000}{6} \\
=R p \cdot 26.350\end{array}$ \\
\hline Peneliti & Rp. 42.000 dari mana didapatkan? \\
\hline Subjek & $\begin{array}{l}\text { uang uang tambahan tiap hari selasa } \\
\text { dan jumat dalam } 1 \text { minggu yaitu } \\
\text { Rp.17000 ditambah dengan uang } \\
\text { tabungan dalam } 1 \text { minggu Rp.25.000, } \\
\text { jadi jumlahnya Rp. } 42.000\end{array}$ \\
\hline Peneliti & uang saku ani perhari? \\
\hline Subjek & Rp.26.350 buk \\
\hline Peneliti & $\begin{array}{l}\text { apakah ananda yakin dengan } \\
\text { jawabannya? }\end{array}$ \\
\hline Subjek & yakin buk \\
\hline
\end{tabular}

Pada saat tes awal subjek kurang teliti dalam melaksanakan rencana penyelesaian. Karena pada Gambar terlihat bahwa subjek tidak mempertimbangkan apa yang ditanyakan soal. 


\section{b. Akhir}

Pada tahap tes akhir subjek sudah melakukan prosedur yang benar dan mendapatkan hasil yang benar, yang dapat dilihat pada Gambar 5

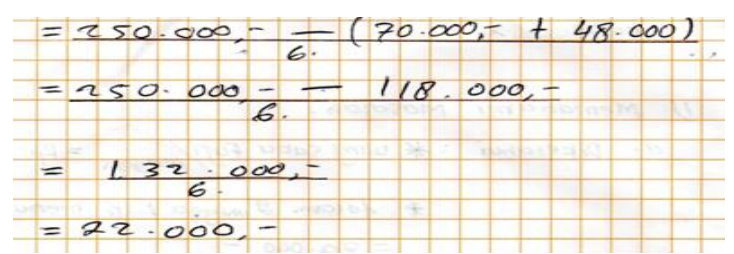

Gambar 5 jawaban tes akhir subjek

Pada Gambar terlihat bahwa subjek sudah melaksanakan penyelesaian sesuai dengan rencana yang sudah ditentukan dan mendapatkan jawaban yang benar, dimana jawaban tersebut juga dipertegas dalam wawancara dengan subjek dibawah ini

\footnotetext{
Peneliti kemudian dari rencana bagaimana cara ananda melaksanakan rencana tersebut?

Subjek uang saku fuji selama 2 minggu kan Rp.250.000 dikurang dengan uang tabungan fuji Rp.70.000 dikurang lagi dengan uang yang dibutuhkan Rp.48.000 trus dibagi 6

Peneliti Rp.48.000 didapatkan dari mana?

Subjek 6 hari dikali 8.000

Peneliti kenapa 6 hari?

Subjek hari les fuji perminggu 3 hari, 2 minggu tu 6 hari buk makanya $6 x$ Rp. $8.000=$ Rp.48.000 kemudian dibagi 6

Peneliti kenapa dibagi 6?

Subjek karena selain hari les ani belajar 2 minggu 6 hari. Didapatkan hasilnya Rp.132.000 kemudian dibagi 6 hasilnya Rp.22.000

Peneliti apakah ananda yakin dengan jawabannya

Subjek yakin buk
}

Pada pernyataan wawanacara tersebut subjek sudah biasa melaksanakan penyelesaian dengan baik dan benar. Dapat dilihat bahwa terjadi peningkatan dalam melaksanakan rencana penyelesaian pada saat tes akhir. Hal ini dikarenakan subjek sudah terbiasa dengan soal pemecahan masalah yang diberikan disetiap pertemuan.

\section{Memeriksa kembali}

Pada tahap memeriksa kembali tes awal dan tes akhir subjek penelitian akan dianalisis perbandingannya. berikut perbandingan tes awal dan tes akhir subjek penelitian

a. Awal

Pada tahap tes awal subjek tidak melakukan pengecekan terhadap hasil jawaban yang diperoleh. Hal ini dikarenakan subjek belum terbiasa menyelesaikan soal pemecahan masalah.

\section{b. Akhir}

Pada tahap tes akhir subjek sudah melakukan pengecekan untuk melihat kebenaran proses. Hal ini dapat dilihat pada Gambar 6 dibawah ini

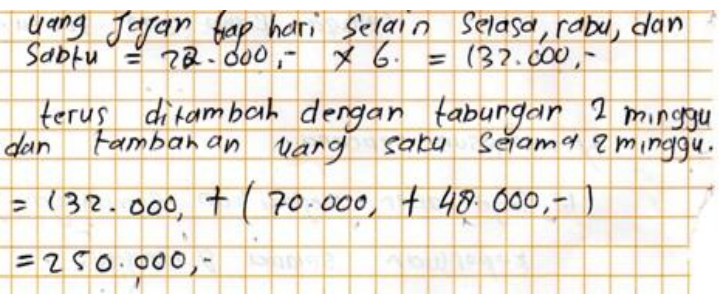

Gambar 6 jawaban tes akhir subjek

Gambar jawaban subjek tersebut juga di pertegas dalam wawancara dibawah ini

Peneliti apakah ananda memeriksa kembali hasil yang diperoleh?

Subjek iya buk

Peneliti bagaimana caranya?

Subjek uang jajan tiap hari selain hari selasa, rabu dan sabtu adalah Rp.22.000 × 6 didapatkan Rp.132.000, kemudian ditambahkan dengan uang tabungan 2 minggu dan tambahan uang saku selama 2 minggu, jadi Rp.132.000 + $R p .70 .000+R p .48 .000=R p .250 .000$

Peneliti bagaimana dengan jawabannya?

Subjek sesuai dengan uang saku selama 2 minggu buk, jadi menurut saya jawabannya benar buk.

Peningkatan terjadi dalam memeriksa kembali jawaban. Dimana subjek sudah memeriksa jawaban yang telah ditulis. Hal tersebut dikarenakan subjek sudah terbiasa dengan soal pemecahan masalah yang 
diberikan disetiap pertemuan diawal pembelajaran.

\section{Kesimpulan dan Saran}

Penelitian mengenai peningkatan kemampuan pemecahan masalah matematika melalui model pembejalaran LAPS-Heuristic kelas X SMAN 2 Batang Anai telah menjawab rumusan masalah yang disusun peneliti. Peningkatan kemampuan pemecahan masalah terjadi pada tahap sebagai berikut:

1. Memahami masalah, terjadi peningkatan pada tahap memahami masalah setelah diterapkannya model pembelajaran $L A P S$ Heuristic, dimana siswa sudah memahami soal dengan baik. Hal ini terlihat ketika siswa dapat menyebutkan apa yang diketahui dan apa yang ditanyakan soal.

2. Menyusun rencana, siswa sudah menyusun rencana yang digunakan dengan baik dan mengarah pada jawaban yang benar.

3. Melaksanakan rencana, setelah diterapkannya model pembelajaran LAPSHeuristic siswa sudah melakukan prosedur yang benar dan teliti sehingga mendapatkan hasil yang benar.

4. Memeriksa kembali, setelah diterapkannya model pembelajaran LAPS-Heuristic siswa melakukan pengecekan pengecekan hasil akhir untuk melihat menghindari kecerobohan yang terjadi selama mengerjakan soal.

Peningkatan tersebut terjadi karena siswa sudah terbiasa dengan soal pemecahan masalah dengan model pembelajaran LAPSHeuristic yang diberikan diawal pembelajaran pada setiap pertemuan.

Dari hasil temuan pembahasan data oleh peneliti, ada beberapa masukan ataupun saran yang ingin disampaikan oleh peneliti. Adapun saran yang ingin disampaikan peneliti kepada beberapa pihak, yaitu sebagai berikut:

1. Bagi siswa, hendaknya kemampuan pemecahan masalah yang dimiliki terus diasah sehingga akan mampu membantu siswa itu sendiri dalam menyelesaikan berbagai soal pemecahan masalah. Begitu juga hendaknya ketelitian dalam memahami masalah selalu dilakukan dalam setiap mengerjakan soal, karena dari temuan penelitian aspek ketidak telitian sering muncul dan itu sangat tidak baik jika terus dibiarkan karena bukan tidak mungkin akan menimbulkan sikap meremehkan hal-hal yang dianggap sepele padahal itu sangat penting.

2. Bagi guru matematika, hendaknya menerapkan model pembelajaran LAPS Heuristic sebagai salah satu alternatif dalam meningkatkan kemampuan pemecahan masalah siswa.

3. Bagi sekolah, dengan adanya hasil penelitian ini hendaknya dapat dijadikan masukan dan pertimbangan bagi sekolah sebagai salah satu alternatif yang dapat ditingkatkan dan dibina dalam mencapai kemajuan semua mata pelajaran terutama matematika, dengan harapan agar bisa menghasilkan pendidikan yang berkualitas dan memiliki kemampuan pemecahan masalah yang tinggi, sehingga pada akhirnya mampu memberikan peran yang penting dalam perubahan yang positif terhadap kemajuan bangsa dan negara.

4. Bagi penulis, hendaknya terus menggali pengetahuan dan pengalaman, sehingga mampu menerapkan ilmu yang sudah diperoleh terhadap kehidupan secara nyata. Sehingga pada akhirnya memberikan manfaat bagi orang lain, tidak hanya untuk diri pribadi dan terutama untuk bisa membawa manfaat bagi perkembangan dunia pendidikan.

5. Bagi peneliti lain, hendaknya dapat dijadikan sebagai acuan dalam penelitian selanjutnya agar mampu memberikan kontribusi bagi upaya peningkatan mutu dan kualitas pendidikan.

\section{Referensi}

Hudojo, H. 2003. Pengembangan Kurikulum dan

$\begin{array}{lrr}\text { Pembelajaran } & \text { Matematika. } & \text { Jakarta: } \\ \text { Departemen } & \text { Pendidikan } & \text { dan } \\ \text { Kebudayaan } & \text { Direktorat } & \text { Jendral } \\ \text { Pendidikan Tinggi. }\end{array}$


Polya, G. 1973. How To Solve It: A New Aspect Oh Mathematical Method. New jersey: Princeton university press.

Shoimin, Aris. 2014. 68 Metode Pembelajaran Inovatif Dalam Kurikulum 2013. Yogyakarta: Ar-Ruzz Media.

Sugiyono. 2013. Metode penelitian pendidikan pendekatan kuantitatif, kualitatif, dan $R \& D$. Bandung: Alfabeta.

--------. 2014. Metode penelitian kuantitatif, kualitatif dan $R \& D$. bandung: Alfabeta.

Yohanes. 2012. Diktat Pendekatan Strategi, Metode, Teknik dan Model Pembelajaran. Universitas Negri Padang. 
JURNAL GANTANG Pendidikan Matematika FKIP - UMRAH

Vol. 1 No. 2, 2016, p-ISSN. 2503-0671, e-ISSN. 2548-5547 